\title{
表面波位相速度法により求めた日本の地殼構造
}

\author{
神 沼 克 伊* \\ The Crustal Structure in Japan from the Phase Velocity of Rayleigh Waves
}

By

\section{Katsutada KAmInUma}

Three earthquakes in the last six years produced satisfactory records of Rayleigh waves, with periods of 20 to 40 seconds, at about 40 stations in Japan operated by the Japan Meteorological Agency. One of these earthquakes was the Samoa shock of April 14, 1957. Epicentral distance of this earthquake from Japan along a path was about $70^{\circ}$ and the waves approached Japan along a path perpendicular to the trend of the island arc (Aki, 1960). Another was the Aleutian shock of March 9, 1957. Epicentral distance was about $35^{\circ}$ and the waves approached Japan along a path parallel to the trend of the islands (Kaminuma and Aki, 1963). The other was the Mindanao shock of September 24, 1957. Epicentral distance was about $33^{\circ}$ and the direction of wave approach from this shock was nearly the reverse of that from the Aleutian shock (Kaminuma, 1964).

Phase velocities for different regions in Japan were determined by the method of least squares applied to the arrival times of selected wave peaks at several stations within each region.

In determing the crustal thickness from the phase velocity, we used the phase velocity curves of Aki's model 6EJ. This model modified Press' model 6EG in such a way that the velocities were uniformly reduced by $5.5 \%$.

The crustal thickness of each region determined by using the three earthquakes are compatible within a limit of probable errors in most regions. But in the Chubu region, the phase velocity of Rayleigh waves propagated parallel to the trend of Japanese Islands is $4 \%$ greater than that for the perpendicular path.

A map of crustal thickness in Japan is drawn by using the phase velocity data of Rayleigh waves from the Samoa, Aleutian and Mindanao shocks as shown in Fig. 5.

長周期表面波のらち，Love 波は，その観測のむずかしさのため，位相速度もあまり求められず，地款。 構造の研究には，ほとんど Rayleigh 波が用いられている。

Rayleigh 波の位相速度を, 地殼構造の研究に, 最初に用いたのは, Press (1956)である。Press は 3 観 測点を使つて, 波の位相速度とその伝播方向とを求めた。

安芸(1961) は, 気象庁ウィーヘルト観測網を利用し, 観測点をいくつかの地域に分け (第 2 図参照), 最 小自乗法を適用する巧妙な方法により，日本全体の地殼構造を推定した。後述するように，この方法によ

$*$ 東京大学理学部地球物理学教室 


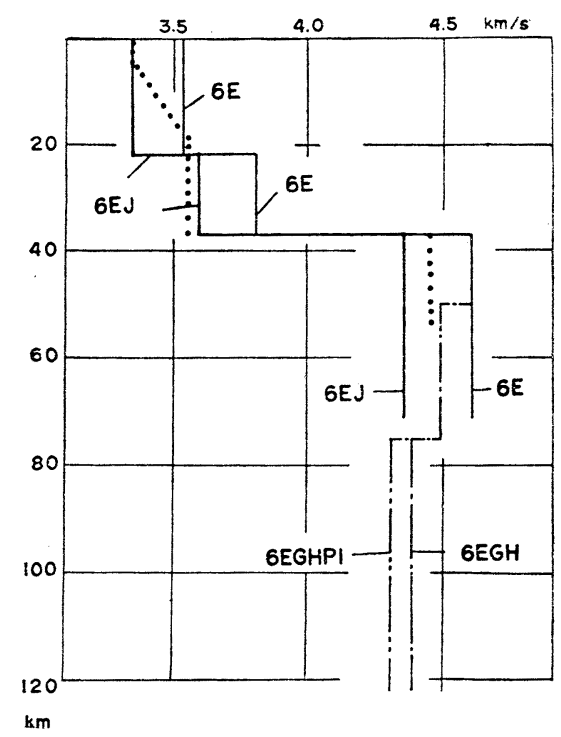

第 1 図地泼及び上部マントルモデルの 横波速度分布。6 EG のモデルは Press によ る標準大陸モデル。6 EJ は安芸による日本における位相速度に適合するモデル

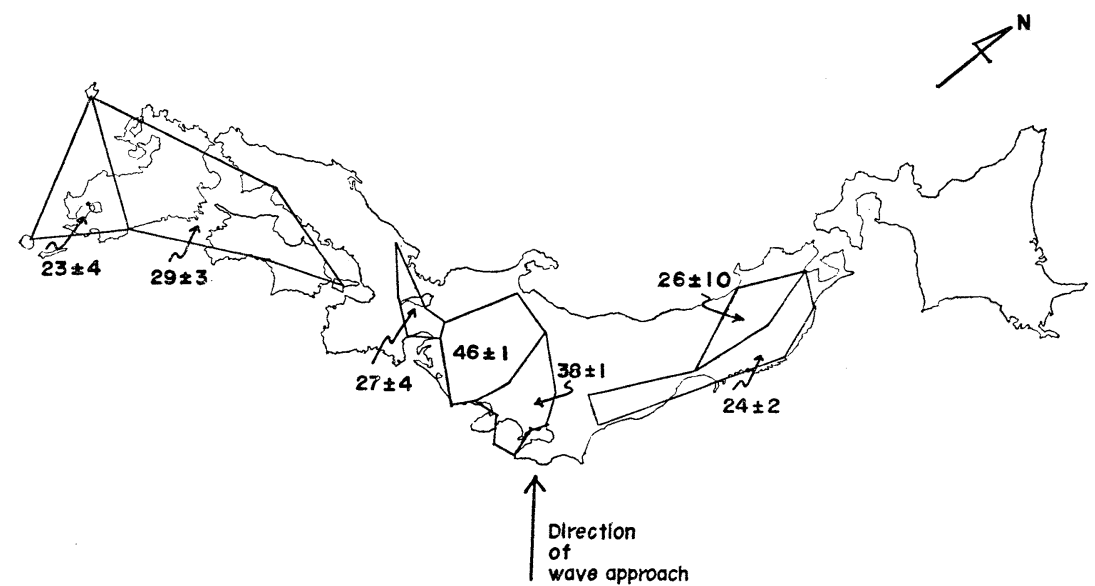

第 2 図 サモア地震によるレーリー波の位相速度より求めた各地域の地殼の厚さ

(Aki, 1961)

り, 今までに, 伝播方向の異なる三つの地震による Rayleigh 波の位相速度から, 日本の地款構造を求め た。

I）位相速度法

地殼構造を推定するには, Rayleigh 波の位相速度を精度良く求める。求めた位相速度の分散と, いく つかのモデルの分散曲線とを比較する。そして観測された分散に良く一致するモデルを選び，その地殼の 㫗さを決める。したがつて, 求められた結果は, 「ある一つのモデルで, ある地域の地下構造が説明出来 るとすれば, その地域での地款の厚さは, この值をとる」という意味である。 


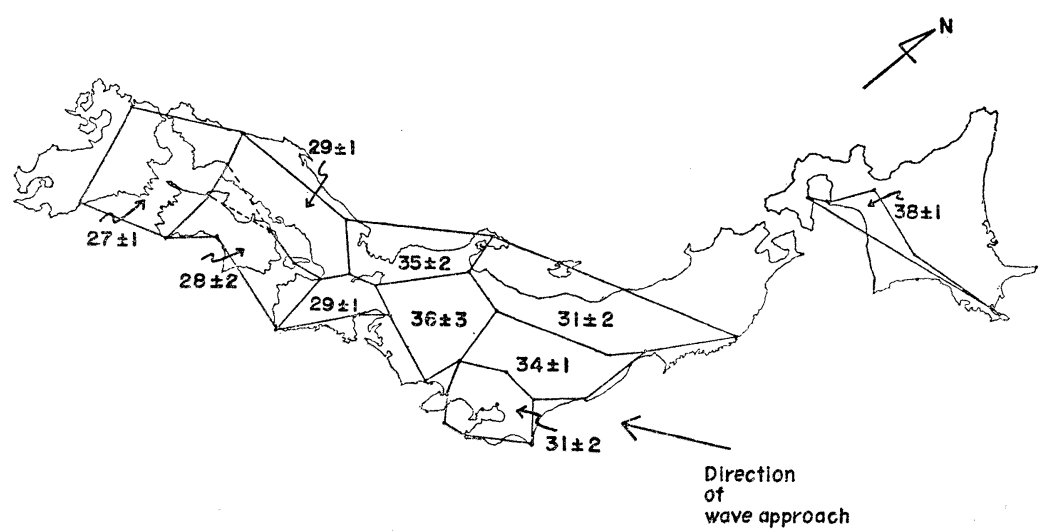

第 3 図アリューシャン地震によるレーリー波の位相速度より求めた各地域の地殼の厚さ

(Kaminuma and Aki, 1963)

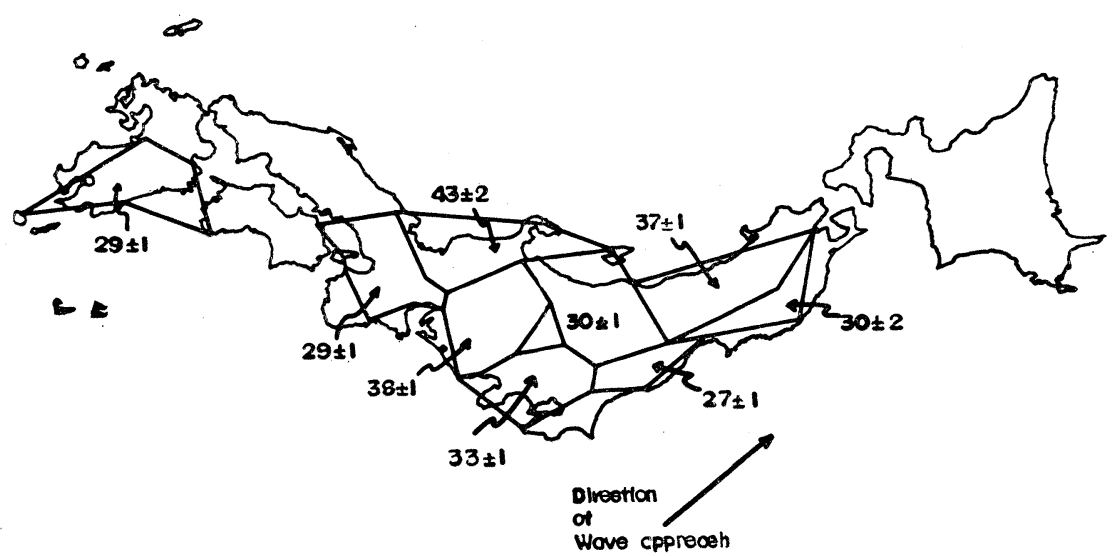

第 4 図ミンダナオ地震によるレーリー波の位相速度より求めた各地域の地殼の厚さ

(Kaminuma, 1964)

現在, 筆者等が用いているモデルは, 安芸 (1961) が, Press の仮定した大陸の標準モデルである, いわ 河るモデル $6 \mathrm{E}$ の弾性波速度を $5.5 \%$ 遅くなるように修正したモデル $6 \mathrm{EJ}$ である。

この方法は，爆破地震の観測結果と，表面波が十分に分散した記録とがあれば，比較的容易に，かなり 広、地域の構造が決められる。また周期 50 秒以上の波を使えば，地殼ばかりでなく， upper mantle の構 造も十分に議論することが出来る。

しかしながら，現在の周期範囲(20 40 秒)では, 波長にして, 約 $100 \mathrm{~km}$ 以下のモ木面の凹凸など, あ まり細かい議論が出来ない。また，たとえ 10 20 秒の周期の波が観測可能であつても，地震計の密度が 増さない限り，同様である。

II）日本の地殼構造

Rayleigh 波の位相速度を用いて，今迄に，次の三つの地震によつて，日本の地款構造を決めた。すな わち，サモア地震 (Apr. 14，1957， $\triangle \doteqdot 70^{\circ}, M=7.0:$ Aki，1961)，ア!ューシャン地震 (Mar. 9， 1957, $\Delta \div 35^{\circ}, M=8-81 \frac{1}{2}:$ Kaminuma and Aki, 1963), そしてミンダナオ地震 (Sept. $24,1957, \Delta \div 30^{\circ}, M=$ $7 \frac{3}{4}$ : Kaminuma, 1964)である。これらの波は, 日本列島に対し, 大体直角又は北東方向か南西方向より 


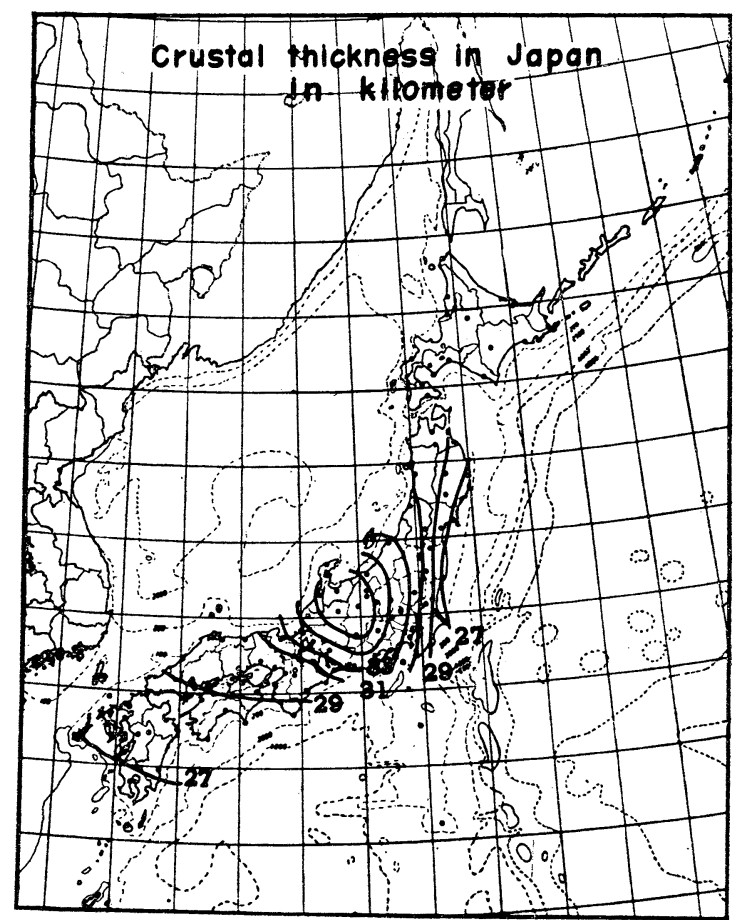

第 5 図 レーリー波位相速度法により求めた日本の地殼の厚さ

(Kaminuma, 1964)

平行に入射してきている。このような，伝播方向の異なる波を使えば，モホ面の異方性もある程度解り得 る。また，位速速度の誤差は $1 \sim 2 \%$ ある。

第 2，3，4図には，それぞれの場合の各地域の地殼の厚さを示した。大体は誤差の範囲で一致するが, 中部地域のように，日本列島に対して，波が直角に入る方が，平行に入る場合より，位相速度が遅い（し たがつて，地款は厚い）といら地域もある。第 5 図は，第 2，3，4図を基にして引いた，日本の地殼のコ ンターである。北海道については，資料がアリューシャン地震の場合のみであるので除外した。

西日本では, 西にゆくにしたがい, ゆるやかに薄くなり, 東北日本では, 太平洋側が急速に薄くなつて いる。中央日本では，琵琶湖附近から東にむかつて急に深くなつている。

第 5 図は，今迄得られている爆破の結果とも良く一致する。また，金森(1963)が reduced Bouguer anomaly から求めたモホ面のコンターとも大体一致する。

勿論, 日本列島全体を一つのモデルにあてはめることに対する疑問はあるが, 第 5 図は日本の地殼構造 を，かなり良く示していると思われる。

Reference

1) Aki, K. : Crustal Structure in Japan from the Phase Velocity of Rayleigh Waves, Part 1, Use of the network of seismological stations operated by the Japan Meteorogical Agency, Bull. Earthq. Res. Inst., 40, 255-283, 1961.
2) Kaminuma, K. and K. Aki : Crustal structure in Japan from the Phase Velocity of Rayleigh Waves, Part 2, Rayleigh Waves from the Aleutian Shock of March 9, 1957, Bull. Earthq. Res. Inst., 41, 217-241, 1963. 
3) Kaminuma, K. : Crustal structure in Japan from the Phase Velocity of Rayleigh Waves, Part 3, Rayleigh Waves from the Mindanao Shock of Sept. 24, 1957, in press.

4) Kanamori, H. : Study on the Crust-mantle Structure in Japan, Part 2, Interpretation of the Results Obtained by Seis- mic Refraction Studies in Connection with the Study of Gravity and Laboratory Experiments, Bull. Earthq. Res. Inst., 41, 761-779, 1963.

5) Press, F. : Determination of Crustal Structure from Phase Velocity of Rayleigh Waves, Part 1 : Southern California,Bull. Geol. Soc. Am., 67, 1647-1658, 1956. 